\title{
Analisis Kesadaran Metakognisi Dan Hasil Belajar Kognitif Mahasiswa Melalui Strategi Review Artikel Ilmiah
}

\author{
Rahma Widiantie \\ Program Studi Pendidikan Biologi FKIP Universitas Kuningan \\ rahmawidiantie@gmail.com
}
APA Citation: Widiantie, R. (2021). Analisis Kesadaran Metakognisi Dan Hasil Belajar Kognitif Mahasiswa Melalui Strategi Review Artikel Ilmiah. Quagga: Jurnal Pendidikan dan Biologi, 13(1), 88-94. doi: 10.25134/quagga.v13i1.3826.

Received: 20-11-2020

Accepted: 28-12-2020

Published: 01-01-2021

\begin{abstract}
Abstrak: Mahasiswa masih kesulitan dalam mengelola informasi baru dan menghubungkannya dengan materi yang telah diterima sebelumnya. Kondisi tersebut terlihat pada hasil belajar kognitif mahasiswa yang masih banyak dalam kategori cukup. Tujuan penelitian ini untuk menganalisis pengaruh strategi review artikel ilmiah terhadap kesadaran metakognisi dan hasil belajar mahasiswa serta menganalisis hubungan kedua variable tersebut. Sampel adalah mahasiswa yang menempuh mata kuliah Endokrinologi dengan desain penelitian one shot case study. Hasil penelitian terdapat peningkatan hasil belajar kognitif mahasiswa yaitu 25,9\% kategori sangat baik, 51,9\% kategori baik dan 22,2\% kategori cukup. Kesadaran metakognisi adalah 79,8\% dengan kategori baik dimana nilai tertinggi pada pengetahuan kondisional. Hasil uji statistic multivariant annova adalah pembelajaran menggunakan review artikel ilmiah berpengaruh terhadap kesadaran metakognisi dan hasil belajar kognitif mahasiswa. Hasil uji korelasi menunjukkan bahwa terdapat hubungan positif antara kesadaran metakognisi dengan hasil belajar kognitif dengan nilai korelasi 0,886. Hasil penelitian secara keseluruhan adalah terdapat peningkatan hasil belajar kognitif dan kesadaran metakognisi mahasiswa, terdapat pengaruh yang signifikan pembelajaran menggunakan review artikel ilmiah terhadap kesadaran metakognisi dan hasil belajar kognitif serta terdapat korelasi yang positif antara kedua variable tersebut. metakognisi menekankan pemantauan dan tanggung jawab diri siswa, sehingga siswa dapat mengatur dirinya untuk merencanakan, memantau dan mengevaluasi tujuan pembelajarannya sehinggan dapat meningkatkan hasil belajar kognitifnya
\end{abstract}

Kata- kata kunci: Kesadaran metakognisi; Hasil belajar kognitif; Review artikel ilmiah

Abstract: Students still have difficulty managing new information and relating it to previously received material. This condition can be seen in the cognitive learning outcomes of students who are still in the sufficient category. The purpose of this study was to anlyze the effect of scientific article review strategies on metacognition awareness and student learning outcomes and the relationship between the two variables. The sample was students taking the Endocrinology course with a one-shot case study research design. The results of the study showed an increase in student cognitive learning outcomes, $25.9 \%$ very good category, $51.9 \%$ good category and $22.2 \%$ sufficient category. Metacognition awareness was $79.8 \%$ with the good category where the highest score was on conditional knowledge. The result of the Annova multivariant statistical test is that learning using scientific article reviews has an effect on metacognition awareness and cognitive learning outcomes of students. The results of the correlation test showed that there was a positive relationship between metacognition awareness and cognitive learning outcomes with a correlation value of 0.886. The results of the study as a whole are there is an increase in student cognitive learning outcomes and metacognition awareness, there is a significant effect of learning using scientific article reviews on metacognition awareness and cognitive learning outcomes and there is a positive correlation between the two variables. Metacognition emphasizes monitoring and selfresponsibility of students, so that students can organize themselves to plan, monitor and evaluate their learning goals so that they can improve their cognitive learning outcomes.

Keyword: Cognitive learning outcomes, Metacognition awareness, Scientific article reviews

\section{PENDAHULUAN}

Mata kuliah Endokrinologi yaitu mata kuliah yang mempelajari tentang anatomi, fisiologi dan abnormalitas yang terjadi pada kelenjar endokrin pada manusia. Kelenjar endokrin yang dikaji adalah kelenjar hipofisa, kelenjar tiroid, kelenjar pancreas, kelenjar adrenal dan kelenjar testis/ovarium. Penyampaian materi kelenjar endokrin tidak cukup hanya dengan ceramah dan pemberian tugas saja, namun dibutuhkan aplikasi untuk 
menyelesaikan permasalahan berkaitan dengan kelenjar endokrin, sehingga mahasiswa dapat membangun konsepnya sendiri. Perkembangan ilmu pengetahuan mengenai materi endokrinologi berkembang dengan pesat ditandai dengan semakin banyak penelitian-penelitian yang mengkaji endokrin baik tentang pengobatan abnormalitas kelenjar endokrin maupun penemuan hormone-hormon baru yang mempunyai fungsi penting dalam fisiologis harian manusia. Kondisi tersebut memberikan dampak kepada pembelajaran materi endokrin, dimana perkuliahan harus disesuaikan dengan perkembangan materi berdasarkan hasil penelitian tersebut. Hasil penelitian sebelumnya menunjukkan mahasiswa masih kesulitan dalam mengelola informasi baru dan menghubungkannya dengan materi yang telah diterima sebelumnya. Kondisi tersebut terlihat pada hasil belajar kognitif mahasiswa yang masih banyak dalam kategori cukup dalam menguasai konsep endokrin (Widiantie, 2017).

Metakognisi mencakup pemahaman dan keyakinan pembelajar mengenai proses kognitifnya sendiri dan bahan pelajaran yang akan dipelajari, serta usaha-usaha sadarnya untuk terlibat dalam proses berperilaku dan berpikir yang akan meningkatkan proses belajar dan memorinya (Omrod, 2009). Berpikir dihasilkan dari metakognisi yang dimiliki setiap manusia. Secara ringkas dapat dinyatakan bahwa metakognisi adalah kesadaran (awarenes) seseorang tentang proses pemantauan (monitoring) serta menjaga dan mengendalikan (regulating dan controling) pikiran dan tindakannya sendiri. Dengan demikian, metakognisi amat diperlukan dalam kegiatan berpikir mahasiswa (Flavel dan Miller, 1993).Untuk memfasilitasi dan meningkatkan kesadaran metakognisi mahasiswa maka pada mata kuliah endokrinologi menuntut setiap mahasiswa untuk mencari artikel ilmiah nasional dan internasional yang relevan dengan kelenjar endokrin baik itu fisiologis hormonnya maupun cara mengatasi abnormalitas yang berhubungan dengan kelenjar endokrin,kemudian mahasiswa melakukan analisis terhadap artikel tersebut dan melakukan evaluasi dengan cara menghubungkan dengan materi yang telah diterima sebelumnya. Mahasiswa dituntut untuk menghubungkan informasi baru dari artikel ilmiah dengan materi yang telah diterima sehingga mahasiswa dapat membangun konsepnya sendiri. Melakukan analisis jurnal juga dapat melatih kesadaran metakognisinya sehingga akan memberikan dampak yang positif terhadap hasil belajar kognitifnya.

Kegiatan menganalisis artikel ilmiah merupakan salah satu bentuk belajar untuk mempelajari perkembangan suatu teori atau suatu ilmu. Dengan menganalisis artikel ilmiah, mahasiswa akan mendapatkan informasi yang akan menambah pengetahuannya tentang suatu ilmu yang dipelajari (Rahayu, 2016). Seperti mata kuliah Endokrinologi, selain memahami teori-teori dasar tentang ilmu fisiologis kelenjar endokrin pada manusia, sebaiknya ilmu tersebut diperkaya pula dengan informasi-informasi baru tentang perkembangannya melalui hasil penelitian yang berkaitan dengan kelenjar endokrin.

Pada proses pembelajaran mahasiswa yang berhasil adalah mahasiswa yang secara sadar dapat memonitor dan mengontrol aktivitas belajarnya. Kognisi dan metakognisi merupakan dua komponen penting dalam pembelajaran mandiri, khususnya dalam pembelajaran sains. Belajar mandiri pada dasarnya mencakup tiga komponen penting, yaitu kognisi, metakognisi dan motivasi. Beberapa peneliti percaya bahwa komponen tersebut khususnya metakognisi penting karena memungkinkan individu untuk merencanakan dan mengalokasikan sumber belajar yang terbatas dengan seefisien mungkin, mengawasi tingkat pengetahuan dan keterampilan yang dimiliki, serta mengevalausi kondisi belajarnya (Schraw et al, 2006). Berdasarkan pemaparan diatas mengenai pentingnya memfasilitasi dan meningkatkan kesadaran metakognisi mahasiswa terutama strategi mengelola informasi, strategi perbaikan dan evaluasi serta meningkatkan hasil belajar kognitif mahasiswa maka dalam perkuliahan endokrinologi mahasiswa diharuskan untuk melakukan analisis artikel ilmiah dan menghubungkannya dengan materi yang telah diterima dengan harapan dapat meningkatkan kesadaran metakognisinya dan meningkatkan hasil belajar kognitifnya 
secara keseluruhan. Penelitian ini menganalisis kesadaran metakognisi, hasil belajar kognitif mahasiswa, pengaruh pembelajaran endokrin dengan review artikel ilmiah dan hubungan antara kesadaran metakognisi dan hasil belajar kognitif mahasiswa.

\section{METODOLOGI}

Metode penelitian yang digunakan dalam penelitian ini adalah pre-experimental design dengan desain one-shot case study, dalam penelitian ini, tidak ada kelompok kontrol (Cresswell, J.W, 2017). Sampel berjumlah 27 orang mahasiswa yang sedang menempuh mata kuliah Endokrinologi. Instrumen yang digunakan adalah tes tertulis berbentuk uraian (Quiz, UTS, dan UAS) untuk mengukur hasil belajar kognitif, Angket Metacognitive Awareness Inventory (MAI) (Schraw dan Sperling- Dennison, 1994) untuk mengukur kesadaran metakognisi mahasiswa dan Rubrik penilaian review artikel ilmiah dikembangkan pada penelitian sebelumnya (Widiantie, 2018). Uji statistic yang digunakan adalah statistic deskriptif untuk menganalisis kesadaran metakognisi dan hasil belajar kognitif mahasiswa, uji Multivariat Annova (GLM Mannova), serta uji korelasi pearson untuk menguji hubungan kesadaran metakognisi dan hasil belajar kognitif.

\section{HASIL DAN PEMBAHASAN}

Nilai hasil belajar diperoleh dari UTS, Quiz, dan UAS mata kuliah endokrin, kemudian diolah dan di analisis secara deskriptif. Hasil belajar kognitif mahasiswa yang berjumlah 27 orang dikategorikan dalam beberapa tingkatan. Hasil belajar kognitif menunjukkan 7 orang atau $25,9 \%$ mahasiswa berada dalam kategori sangat baik, terdapat 14 orang mahasiswa atau $51,9 \%$ mahasiswa berada dalam kategori baik, terdapat 6 orang atau 22,2\% mahasiswa berada dalam kategori cukup dan tidak ada mahasiswa berada dalam kategori kurang dan sangat kurang. Secara umum hasil belajar kognitif mahasiswa secara keseluruhan adalah baik dengan pembelajaran menggunakan review artikel ilmiah, dibandingkan dengan sebelumnya banyak mahasiswa dalam kategori cukup. Data hasil belajar kognitif dihadirkan pada Gambar 1.

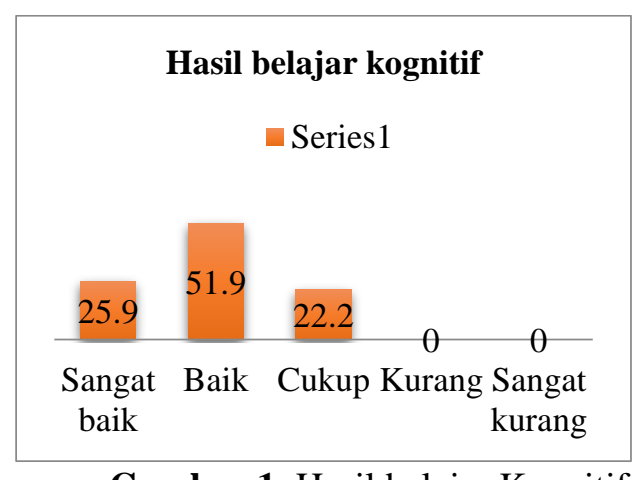

Gambar 1. Hasil belajar Kognitif

Angket Metacognitive Awareness inventory (MAI) yang berisi 52 item pertanyaan terdiri dari pengetahuan tentang kognisi (Pengetahuan deklaratif, Pengetahuan prosedural, Pengetahuan kondisional) dan Regulasi kognitif (Planning, Information management stategies, Comprehension monitoring, Debugging strategies, dan Evaluation). Hasil rekapitulasi kesadaran metakognisi mahasiswa pada gambar 2 .

\section{Kesadaran Metakognisi}

- Series 1

85.9
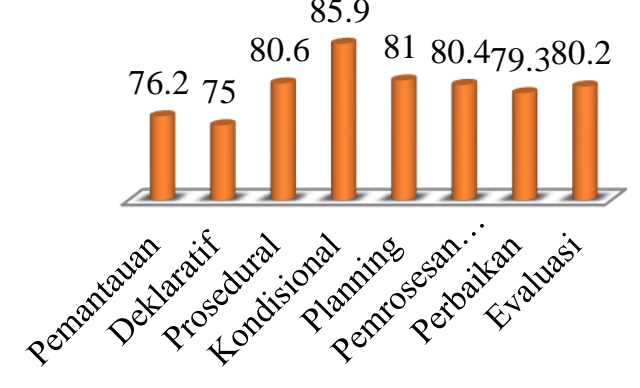

Gambar 2. Kesadaran Metakognisi

Kesimpulannya hasil kesadaran metakognisi adalah baik. Hasil metakognisi tertinggi adalah pengetahuan kondisional dimana mahasiswa mampu menggunakan pengetahuannyan pada beberapa kondisi, mahasiswa dapat mengetahui prosedur belajar yang tepat dalam mengaplikasikan pengetahuannya. Terdapat peningkatan metakognisi mahasiswa pada indicator pemrosesan informasi dan evaluasi karena adanya penerapan review artikel ilmiah. Mahasiswa mempunyai kemampuan dalam mengurutkan strategi secara sistematis dalam menyelesaikan permasalahan pembelajaran dihubungkan dengan materi yang telah 
diterima sebelumnya. Mahasiswa juga mempunyai kesadaran dan keterampilan dalam melakukan evaluasi mengenai strategi belajarnya meliputi waktu, cara dan hasil belajaranya.

Pembelajaran endokrin memanfaatkan artikel ilmiah mengenai kemajuan penelitian yang berkaitan dengan fisiologis kelenjar endokrin. Kemampuan analisis atau review artikel ilmiah mahasiswa dinilai menggunakan rubric penilaian kemampuan analisis artikel ilmiah yang telah dikembangkan pada penelitian sebelumnya. Kemampuan analisis artikel ilmiah adalah sebanyak 44,4\% mahasiswa berada dalam kategori unggul, sebanyak 33,33\% mahasiswa berada dalam kategori kompeten, dan sebanyak 22,22\% mahasiswa berada dalam kategori kompeten parsial, serta tidak ada mahasiswa dalam kategori perlu perbaikan sesuai yang disajikan pada Gambar 3.

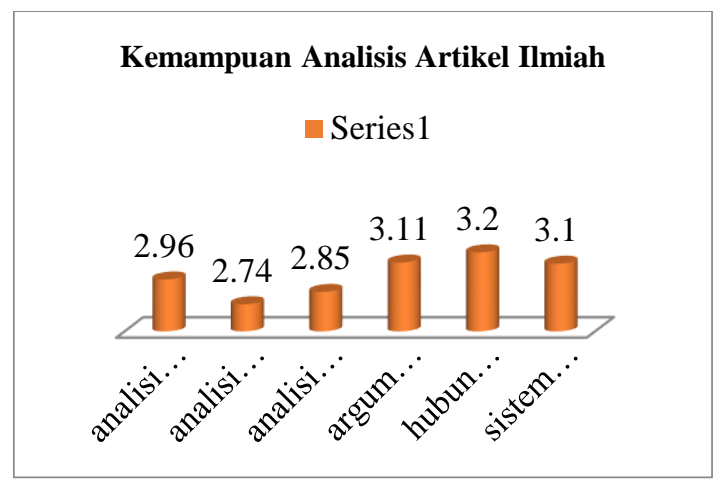

Gambar 3. Kemampuan analisis artikel ilmiah

Hasil review artikel ilmiah, hasil belajar kognitif mahasiswa dan kesadaran metakognisi dilakukan analisis uji statistic menggunakan Multivariat Annova (GLM Manova) untuk mengetahui seberapa besar pengaruh review artikel ilmiah terhadap kesadaran metakognisi dan hasil belajar kognitif.

Hasil uji statistic deskriptif menunjukkan bahwa secara deskriptif rata-rata hasil belajar kognitif paling tinggi adalah mahasiswa yang mempunyai kemampuan analisis artikel ilmiah dengan kategori Unggul dengan nilai 81,26, dan hasil kesadaran metakognisi paling tinggi adalah mahasiswa yang mempunyai kemampuan analisis artikel ilmiah dengan kategori unggul dengan nilai 84,78. Hasil uji multivariate test menunjukkan bahwa ke empat uji statistic yang digunakan adalah signifikan sehingga dapat dikatakan bahwa kemampuan analisis artikel ilmiah mahasiswa secara keseluruhan berpengaruh terhadap kesadaran metakognisi dan hasil belajar kognitif. Hasil uji GLM Manova disajikan pada Gambar 4 dan 5

\begin{tabular}{|c|c|c|c|c|}
\hline \multicolumn{5}{|c|}{ Descriptive Statistics } \\
\hline & $\begin{array}{l}\text { Kemampuan analisis } \\
\text { artikel }\end{array}$ & Mean & Std. Deviation & N \\
\hline \multirow[t]{4}{*}{ Hasil belajar kognitif } & Kompeten parsial & 62.98 & 2.042 & 6 \\
\hline & Kompeten & 74.97 & 2.808 & 9 \\
\hline & unggul & 81.26 & 4.376 & 12 \\
\hline & Total & 75.10 & 7.922 & 27 \\
\hline \multirow[t]{4}{*}{ Metakognisi } & Kompeten parsial & 87.50 & 4.669 & 6 \\
\hline & Kompeten & 81.84 & 10.360 & 9 \\
\hline & unggul & 84.78 & 11.196 & 12 \\
\hline & Total & 84.40 & 9.737 & 27 \\
\hline
\end{tabular}

Gambar 4. Hasil Deskripsi Statistik

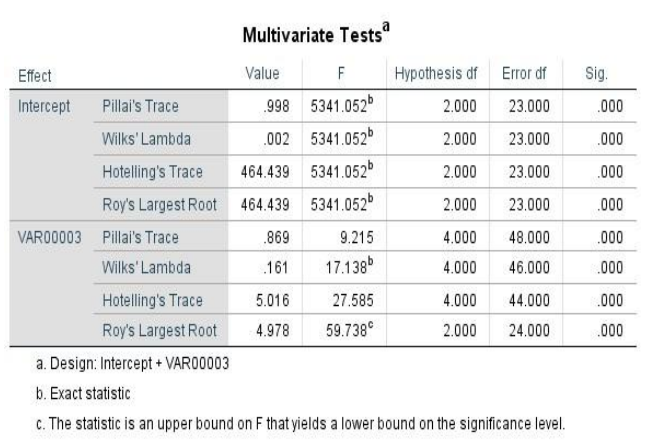

Gambar 5. Hasil Multivariate Tes

Menganalisis artikel ilmiah menuntut mahasiswa untuk berpikir ilmiah dimulai dari menganalisis permasalahan dan hasil penelitian dihubungkan dengan teori. Pembelajaran dengan analisis artikel ilmiah merupakan bentuk belajar untuk mempelajari perkembangan ilmu, mahasiswa akan mendapatkan informasi baru dan mengelola informasi tersebut dengan informasi yang telah diterima sebelumnya sehingga mahasiswa dapat membangun konsepnya sendiri (Williams et all, 2003). Kegiatan review artikel ilmiah digunakan untuk meningkatkan pemahaman mahasiswa terhadap konsep-konsep fisiologis kelenjar endokrin pada manusia. Pada pembelajaran ini mahasiswa setelah memperoleh materi mengenai fisiologis kelenjar endokrin, diminta untuk mencari artikel ilmiah dengan sub materi yang telah ditentukan sebelumnya kemudian mahasiswa melakukan analisis atau review mengenai isi artikel ilmiah dan dihubungkan dengan materi yang telah diperoleh sebelumnya. Pada penilaian review 
artikel ilmiah mahasiswa diminta untuk memberikan argumentasi tentang isi dari artikel ilmiah tersebut. Pemilihan strategi pembelajaran yang tepat dapat meningkatkan metakognisi dan hasil belajar kognitif siswa (Fitriyani, 2015).

Artikel ilmiah memberikan suatu bentuk riil yang didasari dengan teori-teori yang telah ada, sehingga isi artikel ilmiah tersebut dapat memberi contoh nyata yang memudahkan mahasiswa untuk berpikir logis dalam mempelajarinya (Rahayu, 2016). Analisis artikel ilmiah dapat meningkatkan pemahaman mahasiswa terhadap konsep dasar dan aplikasi dari konsep endokrin dalam kehidupan seharihari. Peningkatan pemahaman tersebut berperan dalam meningkatkan hasil belajar kognitif mahasiswa ketika dihadapkan dalam berbagai bentuk soal yang menuntut pemahaman tingkat tinggi. Hal tersebut sesuai dengan hasil penelitian yang menunjukkan rata-rata hasil belajar kognitif sebanyak $25,9 \%$ dengan kategori sangat baik dan sebanyak $51,9 \%$ dengan kategori sangat baik.

Analisis artikel ilmiah yang dilakukan oleh mahasiswa juga dapat melatih pengetahuan dan kesadaran metakognisi mahasiswa. Mahasiswa yang mempunyai pengetahuan dan kesadaran metakognisi yang baik atau tinggi maka akan lebih mudah dalam menyelesaikan tugas belajarnya sehingga mendapatkan hasil yang memuaskan. Ketika mahasiswa dapat meregulasi pengetahuannya sendiri dalam perkuliahan maka mahasiswa dapat mengaplikasikan pengetahuannya dalam berbagai kondisi sehingga dapat meningkatkan prestasi akademiknya. Sebaliknya mahasiswa yang mempunyai pengetahuan dan kesadaran metakognisi cukup atau kurang maka kemampuan regulasinya juga kurang maksimal sehingga akan menghadapi kesulitan ketika dihadapkan pada soal-soal yang berhubungan dengan kehidupan seharihari dan menuntut keterampilan berpikirnya sehingga hasil belajar kognitifnya dalam kategori cukupPada penelitian dihasilkan nilai hasil belajar kognitif dan kesadaran metakognisi melalui pembelajaran endokrin dengan analisis artikel ilmiah. Untuk menjawab pertanyaan penelitian apakah terdapat hubungan antara kesadaran metakognisi dengan hasil belajar kognitif maka dilakukan uji korelasi pearson. Hasil uji korelasi disajikan pada Gambar 6.

\begin{tabular}{|c|c|c|c|}
\hline \multicolumn{4}{|c|}{ Correlations } \\
\hline & & $\begin{array}{l}\text { Hasil belajar } \\
\text { kognitif }\end{array}$ & Metakognisi \\
\hline \multirow[t]{3}{*}{ Hasil belajar kognitif } & Pearson Correlation & 1 & $.886 "$ \\
\hline & Sig. (2-tailed) & & .000 \\
\hline & $\mathrm{N}$ & 27 & 27 \\
\hline \multirow[t]{3}{*}{ Metakognisi } & Pearson Correlation & $.886^{\prime \prime}$ & 1 \\
\hline & Sig. (2-tailed) & .000 & \\
\hline & $\mathrm{N}$ & 27 & 27 \\
\hline
\end{tabular}

Gambar 6. Hasil Korelasi

Hasil uji korelasi diketahui nilai Signifikan antara kesadaran metakognisi dan hasil belajar kognitif adalah sebesar $0,000<0,05$, yang berarti terdapat korelasi yang signifikan antara kesadaran metakognisi dengan hasil belajar kognitif mahasiswa. Nilai $\mathrm{r}$ hitung sebesar $0,886>$ rtabel $(0,3115)$, maka dapat disimpulkan bahwa ada hubungan atau korelasi antara kesadaran metakognisi dengan hasil belajar kognitif. Karena $r$ hitung bernilai positif makaartinya hubungan antara kedua variable dependent bersifat positif atau dapat disimpulkan bahwa peningkatan kesadaran metakognisi juga menyebabkan peningkatan pada hasil belajar kognitif mahasiswa. Hasil uji korelasi menunjukkan terdapat hubungan yang positif antara kesadaran metakognisi dengan hasil belajar kognitif pada pembelajaran endokrin dengan review artikel ilmiah. Hubungan positif artinya adalah jika tingkat kesadaran metakognisi mahasiswa mengalami peningkatan maka hasil belajar juga akan meningkat, dengan kata lain setiap strategi atau usaha yang dilakukan oleh dosen untuk meningkatkan hasil belajar mahasiswa harus mempertimbangkan aspek-aspek kesadaran dan kemampuan metakognisi sebagai salah satu factor internal yang harus diperhatikan, Terdapat hubungan yang signifikan antara keterampilan metakognisi dengan hasil belajar siswa, yaitu hubungan antara planning skill, monitoring skill dan evaluation skill dengan hasil belajar siswa (Nuryana, E, Sugiarto,B, 2012). Menurut Shannon (2008) pengetahuan adalah kekuatan terutama ketika pengetahuan itu tentang bagaimana kita belajar dengan baik, dalam hal ini adalah kemampuan dan kesadaran metakognisi. Hasil penelitian 
Coutinho (2007) juga menunjukkan hubungan yang positif antara kesadaran metakognisi dengan kesuksesan akademik. Mahasiswa yang memiliki kesadaran metakognisi yang baik akan menunjukkan prestasi belajar yang baik pula dibandingkan dengan mahasiswa yang memiliki kesadaran metakognisi rendah. Metakognisi merupakan pengetahuan siswa mengenai kelemahan dan kekuatannya dalam belajar serta pengaturan diri selama belajar berlangsung, seperti perencanaan, penggunaan, proses dan evaluasi, dapat dikatakan terdapat hubungan positif antara metakognisi dengan hasil belajar sehingga diperlukan penerapan strategi yang tepat mengembangkan metakognisi untuk mendapatkan hasil belajar yang maksimal (Abdullah, 2017).

Pembelajaran dengan strategi atau teknik yang mengembangkan kesadaran metakognisi mahasiswa dalam penelitian ini adalah review artikel ilmiah dihubungkan dengan materi fisiologis kelenjar endokrin dapat meningkatkan pengetahuan procedural, pengetahuan kondisional, pemrosesan informasi, perencanaan, serta kesadaran untuk melakukan evaluasi dimana ketika mahasiswa mengalami peningkatan dalam kemampuan dan kesadaran metakognisinya maka akan menyebabkan peningkatan strategi belajarnya sehingga dapat meningkatkan hasil belajar kognitifnya. Terdapat hubungan atau korelasi yang positif antara metakognisi dengan prestasi akademik (Andriani dkk, 2017). Penelitian yang dilakukan oleh Wisdom J. Owo dan Emmanuel F. (2015) menjelaskan bahwa terdapat hubungan yang positif antara metakognisi dengan prestasi akademik.

\section{SIMPULAN}

Pembelajaran Endokrin menggunakan strategi review artikel ilmiah dapat memfasilitasi dan meningkatkan kesadaran metakognisi mahasiswa dengan kategori baik dan hasil belajar kognitif mahasiswa dengan rata -rata dalam kategori baik. Hasil uji statistic menunjukkan terdapat pengaruh yang signifikan pembelajaran terhadap kesadaran metakognisi dan hasil belajar kognitif mahasiswa. Mahasiswa yang mempunyai kemampuan unggul dalam melakukan review artikel ilmiah mempunyai nilai kesadaran metakognisi dan hasil belajar yang baik. Terdapat hubungan yang positif antara kesadaran metakognisi dan hasil belajar kognitif sehingga pembelajaran juga harus memfasilitasi pengembangan kemampuan dan kesadaran metakognisi untuk meningkatkan hasil belajarnya.

\section{REFERENSI}

Abdullah, Ramli, 2017, Urgensi Metakognisi Dalam Pencapaian Hasil Belajar Di SMA, Lantanida Journal, Vol.5, No.2 (2017).

Andriani, dkk, 2017, Hubungan Antara Kemampuan Metakognisi, Motivasi, dan Kesiapan Mental Dengan Hasil Belajar Biologi Siswa Kelas XI IPA SMA Negeri di Kabupaten Gowa, Journal of Biologi Education, Vol.1, No.1. November 2017.

Coutinho, Savia A. 2007. The Relationship Between Goals, Metakognition and Academic Success.Northern Illinois University, United State of America. Educated-vol 7, No 1, 2007.

Cresswell, J.W. (2017). Research Design Pendekatan metode Kualitatif, Kuantitatif, dan Campuran Edisi 4. Yogyakarta: Pustaka Pelajar.

Flavell, Jhon, H and Patricia H, Miller, 1993, Cognitive Development, New Jersey: Prantise Hall

Fitriyani, R., Corebima, A.D., Ibrohim. 2015. Pengaruh Strategi Pembelajaran Problem Based Learning dan Inkuiri TerbimbingTerhadap Keterampilan Metakognitif, Berfikir Kritis, dan Hasil Belajar Kognitif Siswa SMA. Jurnal Pendidikan Sains 3(4): 186-200.

Nuryana, E, Sugiarto, B, 2012, Hubungan Keterampilan Metakognisi Dengan Hasil Belajar Siswa Pada Materi Redoks Kelas X-1SMA Negeri 3 Sidoarjo, Unesa Journal of Chemical Education, Vol.1, No,1, Mei 2012.

OLRC News. 2004. Metacognition. [online]. Tersedia: http://www.literacy .kent.edu/ ohioeff/resource.doc.

Omrod, Jeanne Ellis, 2009, Psikologi Pendidikan Membantu Siswa Tumbuh dan Berkembang, Jilid 1, Jakarta; Erlangga. 
Rahayu, dkk, 2016, Pembelajaran Artikel Ilmiah Untuk Meningkatkan Kemampuan Berpikir Ilmiah, Prosiding Seminar Nasional Pendidikan Biologi FKIP UNS.

Schraw, G and Dennison R.S, 1994, Assesing Metacognitive Awareness, Contemporary Educational Psychology, 19.

Schraw G, Crippen KJ, Harthley K, 2006, Promoting Self Regulation in Science Education: Metacognition as part of a Broader Perspective on Learning. Research in science education.

Shannon, S. V., Collage, W. S. 2008. Using Metakognition Strategis and Learning Styles to Cereate Self-Directed Learns. Institute for Learning Journal. Vol. 1.

Widiantie, R, Handayani, 2017, Kesadaran Metakognisi dan Keterampilan Memecahkan Masalah Mahasiswa Melalui Penugasan Individu
Pembelajaran Berbasis Masalah Materi Endokrin, Jurnal Quagga.

Widiantie, R, Handayani, 2018, Pengembangan Asesmen Keterampilan Berpikir Tingkat Tinggi dan Presentasi Mahasiswa Pada Seminar Pendidikan Biologi, Pendidikan Biologi, Universitas Kuningan.

Williams et.al. 2003. Thinking Like a Scientist About Real-World Problems: The Cornell Institute for Research on Children Science Education Program. Journal of Applied Developmental Psycholog

Wisdom J. Owo dan Emmanuel F. Ikwut, 2015, "Relationship Between Metacognition, Attitude and Academic Achievement of Secondary School Chemistry Students in Port Harcourt, Rivers State," IOSR Journal of Research \& Method in Education (IOSR-JRME) 5, no. 6 . 